\title{
ニッケル触媒による $\mathrm{C}_{3} \sim \mathrm{C}_{7}$ パラフィン炭化水素の水添メタン化反応*1,*2
}

(昭和 42 件 5 月 25 几曼㫵)

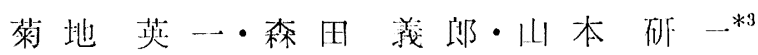

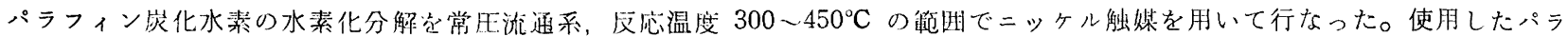
フィン一ープロパン, $n$-ペンタン, $n$-ヘキサン出よび $n$-ヘプタン一からの主生成物はメタンであった。エタン拈よびプロパン のメタンに対する生成此は反応温度の上䄯にともなって減少した。メタンはェタンやプロパンを経由せず直接原料炭化水求から生 成すると思われる。

低温 $\left(300^{\circ} \mathrm{C}\right.$ 以下) に执いては反応は水素によって抑制されるが，この抑制作用は反応温度の上年で減少する。 $300^{\circ} \mathrm{C}$ 以では 水素/炭化水素比が理論水素比の約 1.5 倍以下では反応は水菜によつて促進されるが，てれ以上では反応速度は水絭分仼に上らな くなる。

理諭水素比下での反応性は次の順位で, 炭素数が増加するほど反応性は減少する。

$$
n \text {-ペンタン>n-ヘキサン>n-ヘプタン }
$$

nーペンタン, $n$-ヘキサンおよび $n$-ヘプタンの水添メタン化反応の見かけの活性化ェネルギーはおのおの $7.8,10.0$ および 10.2 $\mathrm{kcal} / \mathrm{mol} ゙$ った。

\section{1 緒言}

ヘキサンの接触水素化分解反応による都市ガス増熱用メタンの 生成にニッケル触媒が $300 \sim 500^{\circ} \mathrm{C}$ で高活性であり，生成物がほ とんどメタンのみよりなることを前報*2で報告した。

ニッケル触媒によるパラフィン炭化水素の水素化分解に関して は Morikawa-Taylor ${ }^{1)}$, Kemball-Taylor ら ${ }^{2)}$ にって研究さ れているが，炭化水素としてはエタン，プロパンが用いられ， 反応温度も $300^{\circ} \mathrm{C}$ 以下である。 $\mathrm{C}_{4}$ 以上の炭化水素については Haensel-Ipatieff ${ }^{3)}$ によるトリメチルペンタン類の選択的脱メチ ル反応に関する報告および Anderson-Baker4)によるニッケル蒸 着膜上での $n$-ブタン, $i$-ブタン, neo-ペンタン, neo-ヘキサンの 水素化分解 $\left(300^{\circ} \mathrm{C}\right.$ 以下) に関する報告があるだけである。

既往のエタン, プロパンの研究で明らかにされている点は, 本 反応は水素化反応であるのにかかわらず，水素によって著しく抑 制される特性があることである。

本報ではメタン化反応が顕著となる $300 \sim 450^{\circ} \mathrm{C}$ でペンタン $\left(n-\mathrm{C}_{6} \mathrm{H}_{12}\right)$ ， ヘキサン $\left(n-\mathrm{C}_{6} \mathrm{H}_{14}\right)$ ， ヘプタン $\left(n-\mathrm{C}_{7} \mathrm{H}_{16}\right)$ の水素化 分解を行ない, 反応生成物，水素分圧の影響を調へ，各炭化水素 の反応性を検討した。またプロパンの水素化分解反応で水素によ る反応抑制の効果を検討した。

*1この報文を「石油の接触水添ガス化反応（第 2 報）」とす る。

*2 前報 (第 1 報), 森田義郎, 菊地英一, 山本研一, 工化, 70,670 (1967).

*3 Eiichi KIKUCHI, Yosiro Morita, Ken-ichi YAMAMOTO 早稲田大学理工学部応用化学科：東京都新宿区西 大久保

1) K. Morikawa, W. S. Benedict, H. S. Taylor, J. Am. Chem. Soc., 58, 1795 (1936).

2) C. Kemball, H.S. Taylor, J. Am. Chem. Soc., 70, 345 (1948).

3) V. Haensel, V. N. Ipatieff, Ind. Eng. Chem., 39, 853 (1947).

4) J. R. Anderson, B.G. Baker, Proc. Roy. Soc. (London), A 271, 402 (1963).

\section{2 実験および方法}

\section{$2 \cdot 1$ 実験装置および方法}

反応瑺王で固定触媒床式流通装置を用いて行なった。装置の 概要および実験方法は前報*2に述べたものとほぼ同じである。

$2 \cdot 2$ 試 料

水素は前報*2同様に精製した。プロパンは市販のボンベ埧め “純プロパン”をそのまま用いた。ガスクロマトグラフ分析に上 る結果 $\mathrm{C}_{3} \mathrm{H}_{8} 96.48 \%, \mathrm{CH}_{4} 0.02, \mathrm{C}_{2} \mathrm{H}_{6} 1.93, \mathrm{C}_{3} \mathrm{H}_{6} 1.52$, 空気 $0.05 \%$ を含む。nーペンタン, $n$-ヘキサン, $n$-ヘプタンは市販 1 級試 薬(純正化学製) をそのまま使用した。nーペンタンおよび $n$-ヘプ タンは純度ほぼ $100 \%$ であり, $n$-ヘキサンは前報*2 と同じである。 $2 \cdot 3$ 触 媒

前報*2で述べた沈貶法触媒で，ニッケル含有量壮 $8.0 \mathrm{wt} \%$ で ある。担体にはシリカゲルを使用した。成型压 $400 \sim 500 \mathrm{~kg} / \mathrm{cm}^{2}$

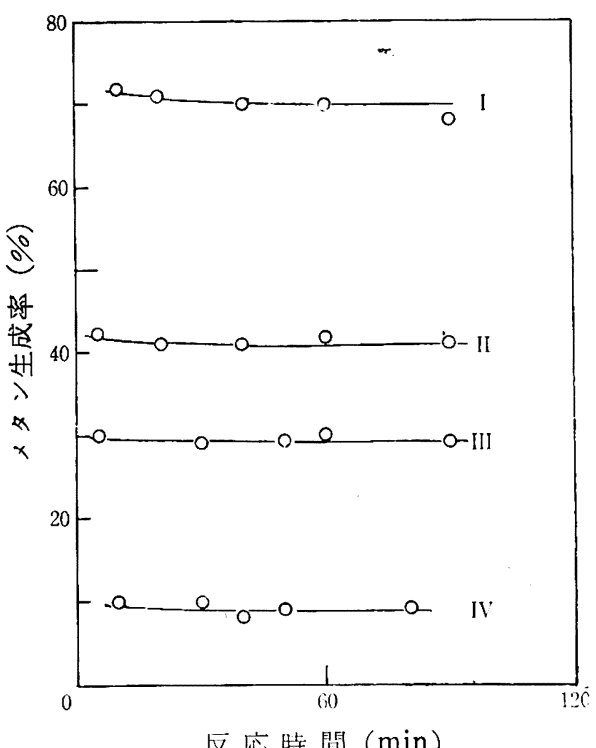

図 1 触媒活性の経時変化

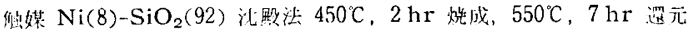
这㤂条作: $n-\mathrm{C}_{6} \mathrm{H}_{14}+5 \mathrm{H}_{2}, 1: 450^{\circ} \mathrm{C}, W / F=20.8 \times 10^{2}, \mathrm{\Pi l}: 350^{\circ} \mathrm{C}$, $W / F=20.8 \times 10^{2}$, nI $: 450 \mathrm{C}, \quad W / F=3,49 \times 10^{2}, \quad N: 350^{\circ} \mathrm{C}, W / F$ $=3,48 \times 10^{2}$ 
で錠剤 $(4 \mathrm{~mm} \phi \times 4 \mathrm{~mm}$ high $)$ にした後， $450^{\circ} \mathrm{C}$ で 2 時間焼成 し使用時に $550^{\circ} \mathrm{C} ， 7$ 時間水素還元した。このように長時間還元 を行なった触媒では㘠 1 に示したよ5に, 你媒活性の安定性が良 好であった。

\section{3 実 験 結 果}

\section{$3 \cdot 1$ 反応生成物亡実験結果表示法}

パラフィン炭化水素の水添メタン化反応は次の量諭式で示され る。

$$
\mathrm{C}_{n} \mathrm{H}_{2 n+2}+(n-1) \mathrm{H}_{2}=n \mathrm{CH}_{4}
$$

(1)式で示される化学量論的水素比を理論水素比とする。理論水 素比で $n$-ペンタン, $n$-ヘキサン, $n$-ヘプタンを水素化分解した 場合の反応生成物を図 2 4 K示した。反応生成物はいずれの炭 化水素の場合もメタンが主成分である。一般に低温ほどエタン, プロパンの生成量が多くなっており，とくに $300^{\circ} \mathrm{C} て ゙ ~ n$ 一キサ ンを水素化分解した時のエタン, プロパンの生成量はメタンの生 成量の $10 \%$ 近くとなる。ブタン以上の炭化水素の生成はェタン,

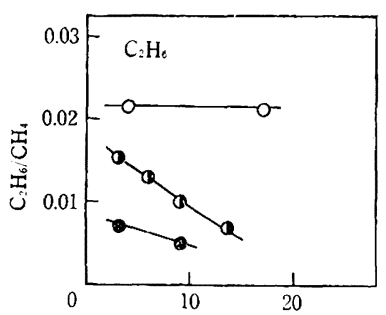

$W / F \cdot\left(10^{-2}\right)$

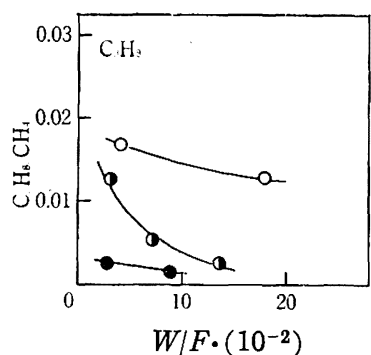

$W / F \cdot\left(10^{-2}\right)$
図 2 n-ペンタンの分解生成物 区応温度 $\mathrm{O}: 300^{\circ} \mathrm{C}, 350^{\circ} \mathrm{C}$,

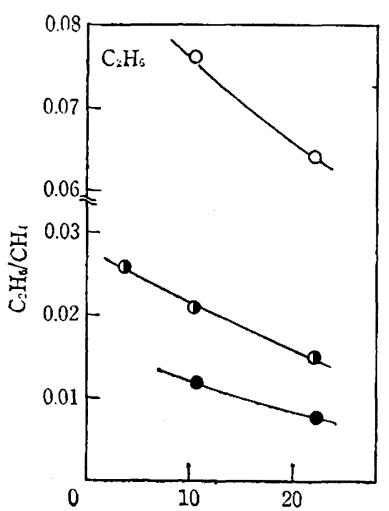

$W / F \cdot\left(10^{-2}\right)$

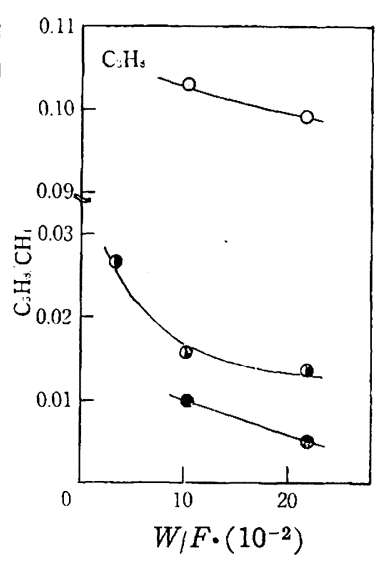

$W / F \cdot\left(10^{-2}\right)$
図 3 n-ヘキサンの分解生成物 反応温度 $\bigcirc: 300^{\circ} \mathrm{C}, \quad: 350^{\circ} \mathrm{C}$,

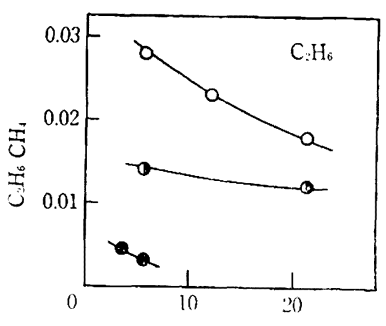

$W / F \cdot\left(10^{-2}\right)$

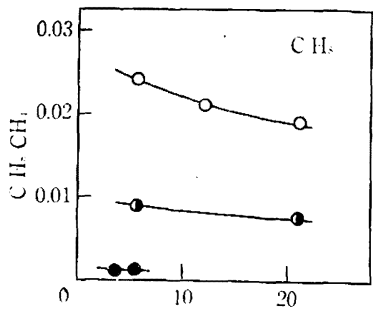

$W / F \cdot\left(10^{-2}\right)$
因 4 nーヘプタンの分解生成物 区応温度 $\mathrm{O}: 350^{\circ} \mathrm{C}, 1: 400^{\circ} \mathrm{C}$,
プロパンよりも少量であった。

エタン，プロパンの生成量をメタンの生成量に対してみてみる と, 生成比は反応温度によって決まってきており, time factor が小さい場合，すなわち低反応率の領域でも生成比はそれほど大 きくならず，メタンに対して $3 \%$ 近くのことが多い。したがっ て, メタン，エタン，プロパンなどの生成は並列的に起こり，生 成するメタンの大部分はエタン，プロパンを中間生成物として経 ていないと考觉られる。

なお本報ではメタンの生成に着目し，エタンプロパンなどの 生成量がメタンの生成量の $3 \%$ 以下となる反応温度での実験につ いて，実験結果を次式によりメタン生成率で整理した。

$$
x_{\mathrm{M}}=\frac{x \text { タン生成量 }(\mathrm{mol})}{\text { 炭化水素 }\left(C_{n} \mathrm{H}_{2 n+2}\right) \text { 送入量 }(\mathrm{mol}) \times(n)}
$$

反応速度は（3）式のよ5に炭化水素がメタンに変化した速度 (mol/min, g・cat) で表わした。

$$
r_{M}=d x_{M} / d(W / F)
$$

ここで $W$ 法触媒重量 $(\mathrm{g}), F$ は炭化水素送入流量 $(\mathrm{mol} / \mathrm{min})$ である。

\section{$3 \cdot 2$ 水素比の影響}

図 5 に n-ヘキサンの水添メタン化反応に扺よ゙す水素分圧の 影響を示した。窒素ガスを希釈剂にして nーヘキサンの初期分圧 $\left(P_{\mathrm{C} 6}{ }^{0}\right)$ を一定とし, 水素初期分王 $\left(P_{\mathrm{H} 2}{ }^{0}\right)$ を変化させた。その結 果 $350 \sim 450^{\circ} \mathrm{C}$ の範囲では，水素分圧の低い場合では水素分圧の 増加にしたがって反応率は増加するが，ある一定分圧以上では水 素分圧の影響を受けない。

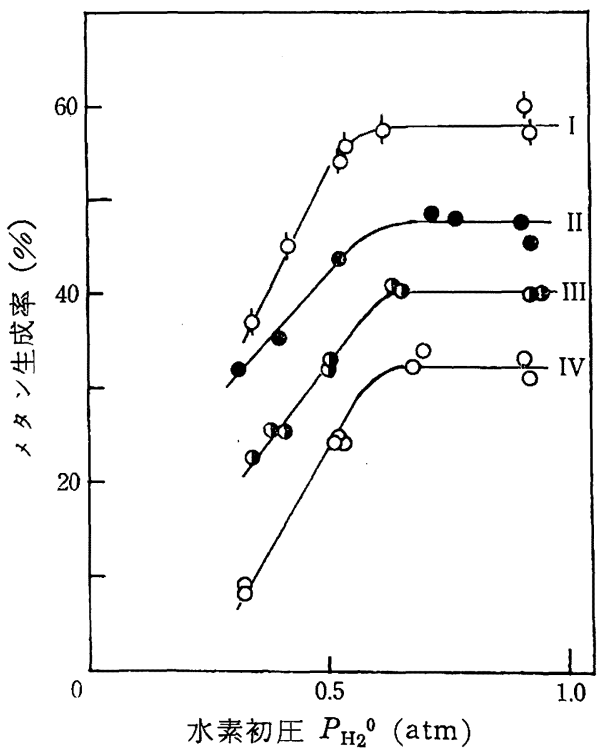

図 5 水素分仕の影響 (I )

反応条件 I $: 350^{\circ} \mathrm{C}, P_{\mathrm{C} \theta^{0}}=0.072 \mathrm{~atm}, W / F=21.0 \times 10^{2}, \mathrm{II}: 450 \mathrm{C}$, $P_{\mathrm{Co}^{0}}=0.075 \mathrm{~atm}, W / F=4.92 \times 10^{2}$, III $: 400^{\circ} \mathrm{C}, P_{\mathrm{Ce}^{0}}=0.075 \mathrm{~atm}$, $W / F=4.92 \times 10^{2}, \mathbb{N}: 350^{\circ} \mathrm{C}, P_{\mathrm{Ce}}{ }^{0}=0.080 \mathrm{~atm}, W / F=4.92 \times 10^{2}$

水素分圧の影響を受けなくなる点は水素分珐の大小によるので はなく，図6に示したように水素と炭化水素の比 $R_{\mathrm{H}}$ によって决

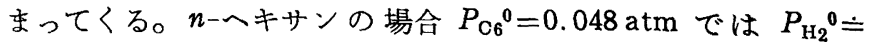
$0.40 \mathrm{~atm}, P_{\mathrm{C} 6}{ }^{0}=0.080 \mathrm{~atm}$ では $P_{\mathrm{H}_{2}}{ }^{0}=0.60 \mathrm{~atm}$ でおのおの $R_{\mathrm{H}}$ $=8.3,7.5$ で理論水素比の $1.5,1.7$ 倍に相当する。また n-ペンタンの場合では理論水素比の 1.5 倍, $n$-ヘプタンの場合 では 1.7 倍である。 


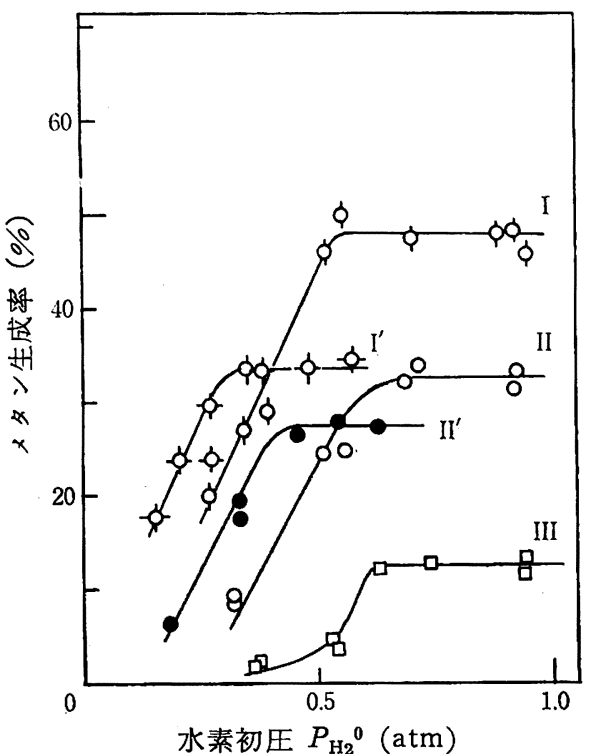

図 6 水素分王の影響（II）

反応条件 : 反応温度 $350^{\circ} \mathrm{C}$

$n-\mathrm{C}_{5} \mathrm{H}_{12}$ I : $P_{\mathrm{C}_{5}}{ }^{0}=0.088 \mathrm{~atm}, W / F=4.35 \times 10^{2}$ I': $P_{\mathrm{C}^{0}}{ }^{0}=0.049 \mathrm{~atm}, W / F=4.35 \times 10^{2}$

$n-\mathrm{C}_{8} \mathrm{H}_{14} \quad$ II $: P_{\mathrm{Co}^{0}}{ }^{0}=0.080 \mathrm{~atm}, W / F=4.92 \times 10^{2}$ II': $P_{\mathrm{Ce}^{0}}=0.048 \mathrm{~atm}, W / F=4.92 \times 10^{2}$ $n-\mathrm{C}_{7} \mathrm{H}_{10} \quad$ III $: P_{\mathrm{C}_{7}{ }^{0}}=0.060 \mathrm{~atm}, W / F=5.87 \times 10^{2}$

\section{$3 \cdot 3$ 理論水素比でのメタン化速度}

・n-ペンタンについて $300 \sim 450^{\circ} \mathrm{C} ， n$-ヘキサンと $n$-ヘプタンに つい 350 $450^{\circ} \mathrm{C}$ で理論水素比の場合の反応速度を比較した。 反応速度は近似的に $n$ 次反応として $(4)$ 式で整理した。

$$
r=k^{\mathrm{N}}\left(1-\frac{x}{x_{\theta}}\right)^{n}=k^{\mathrm{N}}(1-x)^{n}
$$

ここで $k^{\mathrm{N}}\left(k^{0}, k^{\prime}, k^{\prime \prime} \cdots\right)$ は $n$ 次式の場合の見かけ速度定数， $x_{\mathrm{e}}$ は平衡転化率であるが，表 1 に示した平衡定数の值より明らかな ように， $x_{\mathrm{e}}=1$ とみなしてさしつかえない。

表 1 (1)式の反応の平衡定数 $\left(K_{\mathrm{p}}\right)^{\mathrm{a})}$

\begin{tabular}{lccc} 
反纫温度 $\left({ }^{\circ} \mathrm{C}\right)$ & 250 & 350 & 450 \\
\hline $\mathrm{C}_{3} \mathrm{H}_{8}$ & $8.1 \times 10^{13}$ & $7.7 \times 10^{11}$ & $2.4 \times 10^{10}$ \\
$n-\mathrm{C}_{5} \mathrm{H}_{12}$ & $4.6 \times 10^{20}$ & $6.4 \times 10^{22}$ & $9.0 \times 10^{19}$ \\
$n-\mathrm{C}_{6} \mathrm{H}_{14}$ & $8.8 \times 10^{52}$ & $1.4 \times 10^{28}$ & $4.1 \times 10^{24}$ \\
$n-\mathrm{C}_{7} \mathrm{H}_{18}$ & $4.2 \times 10^{38}$ & $8.7 \times 10^{30}$ & $9.4 \times 10^{28}$
\end{tabular}

a) 熱力学データは文献 5)，6）によった.

反応次数 $n$ に $0,1,2 \cdots \cdots$ を代入して実験結果を整理すると $n$ ペンタンで $n=1$ (図 7 ), n-ヘキサンと $n$-ヘプタンで $n=2$ (図 8 ）で良い直線性がえられた。この直線の勾配より求められる見 かけ速度定数は $x_{M}=0$ に扣ける反応速度, 寸なわち初期反応速 度 $r_{0}$ である。初期反応速度のアレニウスプロットを図 9 に示し た。理論水素比での反応性は $n$-ペンタン>n-ヘキサン>n-ヘプ タンの順で，炭素数が大きいほど反応性は悪くなる。見かけの活 性化エネルギーは， n-ペンタン $7.8 \mathrm{kcal} / \mathrm{mol} ， n$-ヘキサン 10.0 $\mathrm{kcal} / \mathrm{mol}, n$-ヘプタン $10.2 \mathrm{kcal} / \mathrm{mol}$ である。

\section{4 水素による反応抑制作用}

ニッケル触媒上での炭化水素の水素化分解に関して従来えられ

5) American Petroleum Institute Research Project 44 (1952).

6) W. C. Edmister, Ind. Eng. Chem., 30, 352 (1938).

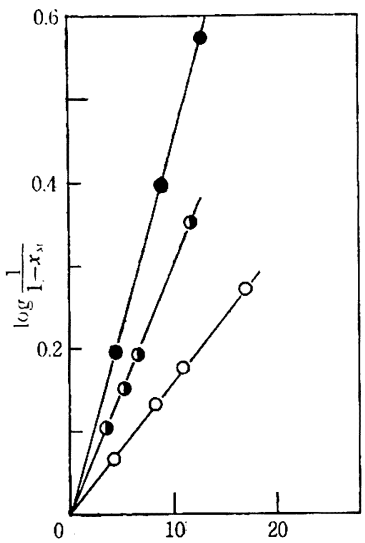

$W / F \cdot\left(10^{-2}\right)$

図 7 n-ペンタンのメタン化速 度（擬 1 次） 反応条件：垩諭水䌽此 $0: 300^{\circ} \mathrm{C}, 0: 350^{\circ} \mathrm{C}, \bigcirc: 400^{\circ} \mathrm{C}$

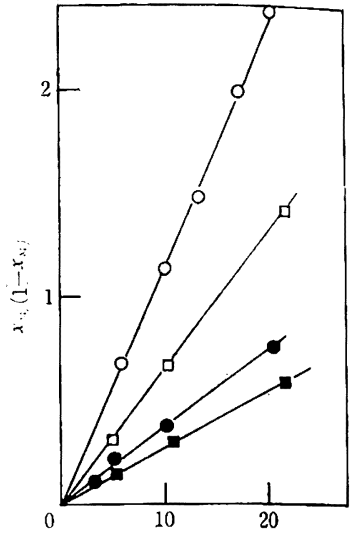

$W / F \cdot\left(10^{-2}\right)$

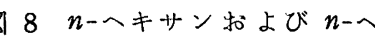
プタンのメタン化速度（擬 2 次)

区応条件: 理論水来比 $n-\mathrm{C}_{8} \mathrm{H}_{14}$ 反心温度 $\mathrm{O}: 450^{\circ} \mathrm{C}, \bigcirc: 350^{\circ} \mathrm{C}$ $n-\mathrm{C}_{7} \mathrm{H}_{18}$ 反㤁温度 $\square: 400^{\circ} \mathrm{C}, \square: 350^{\circ} \mathrm{C}$

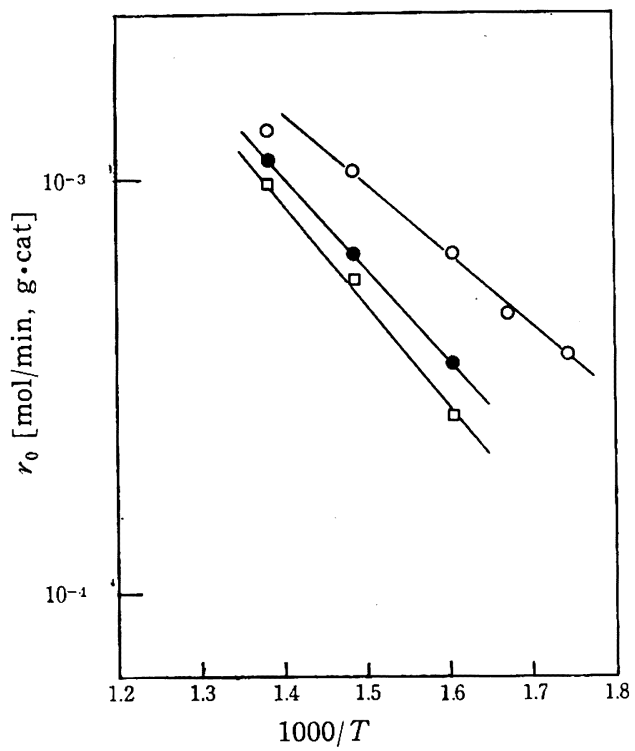

図 9 メタン化速度のアレニウスプロット 反庆条件：理論水䇣此

$\mathrm{O}: n-\mathrm{C}_{5} \mathrm{H}_{12}, \bullet: n-\mathrm{C}_{6} \mathrm{H}_{14}, \square:{ }_{n}-\mathrm{C}_{7} \mathrm{H}_{10}$

ている結果は，前述したよ5に反応が水素によって大きく抑制さ れるとい5特性である。しかし $3 \cdot 2$ に述べたように $\mathrm{C}_{5} \sim \mathrm{C}_{7}$ のパ ラフィン炭化水素ではこのよ5な特性は認められなかった。既往 の研究はエタン, プロパンについて $300^{\circ} \mathrm{C}$ 以下の反応温度でなさ れているので, このよ5な水素の作用の違いの原因として，炭化 水素むるいは反応温度域の違いが考えられる。そこでプロパンの 水素化分解を $250,300,350^{\circ} \mathrm{C}$ で行なって水素分圧の影響を調べ た*4。その結果，図 10 に示与ように低温側では明らかに水素に よって反応が抑制される。反応温度が高くなるにしたがって抑制 作用は小さくなり, $300^{\circ} \mathrm{C}$ ではほとんど影響なく $350^{\circ} \mathrm{C}$ では全く， 抑制作用がみられず，3・2 と同様の結果がえられたしたがって 水素の作用はおむに反応温度によって異なってくると考えられる。

*4 使用したプロパンは少量のェタンを含むこと，および $C_{1}$ $\sim \mathrm{C}_{3}$. 屯での分析が容易で正磼なことから，プロパンの場 合にはプロパンの反応率で実験結果を表わした。 


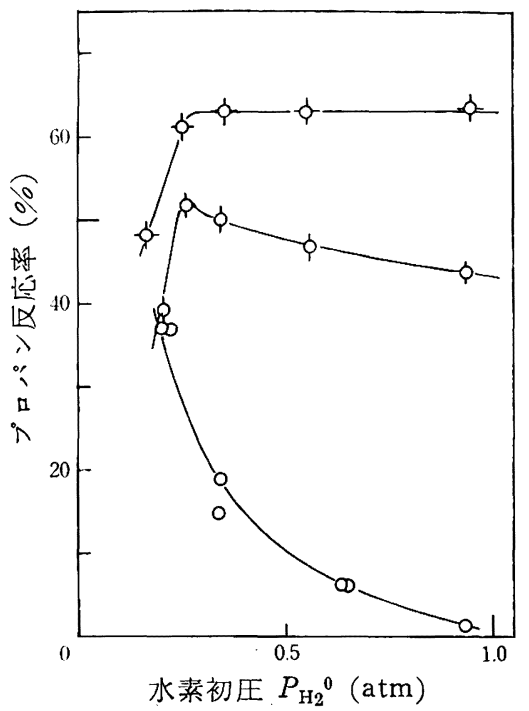

図 10 プロパンの水素化分解におよぼす水素分圧の影響

反必条件 $O: 250^{\circ} \mathrm{C}, P_{\mathrm{C}_{3}{ }^{0}}=0.063 \mathrm{~atm}, W / F=4.62 \times 10^{2}$ O: $300^{\circ} \mathrm{C}, P_{\mathrm{C}_{3}}{ }^{0}=0.058 \mathrm{~atm}, W / F=4.06 \times 10^{2}$ b: $350^{\circ} \mathrm{C}, P_{\mathrm{C}_{3}}{ }^{\circ}=0.058 \mathrm{~atm}, W / F=4.06 \times 10^{2}$

\section{5 反応次数}

初期反応速度に拈よぼす水素の次数は 3.4 に述べたよ5に反応 温度によって異なるが, $300^{\circ} \mathrm{C}$ 以上では $n$-ペンタン, $n$-ヘキサ ソ, n-ヘプタンともに理論水素比の $1.5 \sim 1.7$ 倍以上の水素比で

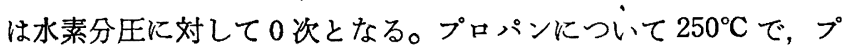
ロパン初圧 $0.063 \mathrm{~atm}$ にして低温における水素の反応抑制作用 をみると図 11 に示したように水素に対して -1.8 次となる*5。

炭化水素の次数は水素初圧を一定にして, 図 12 に示した炭化 水素初圧と初期反応速度の関係から求めた。プロ パンでは $250^{\circ} \mathrm{C}$ で 1.0 次となる。また $300,350^{\circ} \mathrm{C}$ で水素に対して 0 次となる水 素比では括の拈の $1.1,1.0$ 次となり，炭化水素の次数は反応温 度によって変わらない。

$n$-ペンタン, $n$-ヘキサン, $n$-ヘプタンの 次数は理論水素比の 1.5 倍以上の水素比で求めた。反応速度は図 13 に示したように 擬 1 次式で求められる。図 12 より次数は $n$-ペンタンに対して 0.7 次 $\left(300,350^{\circ} \mathrm{C}\right), n$-ヘキサンおよび $n$-ヘプタンに対して 0.5 次 $\left(350^{\circ} \mathrm{C}\right)$ である。

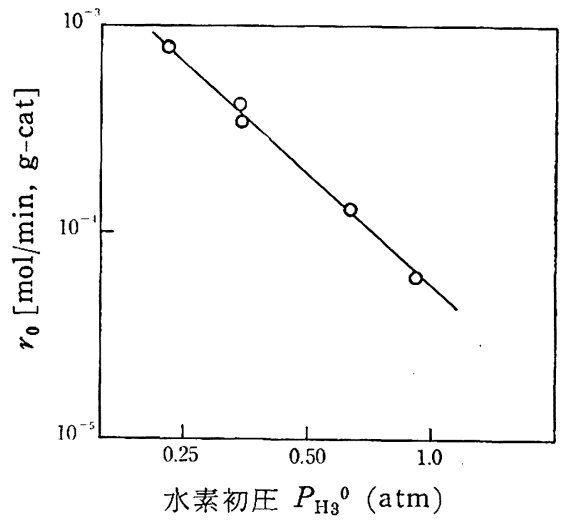

図 11 低温に括ける水素の反応抑制作用 反応采件：反応洫㢃 $250^{\circ} \mathrm{C}$

原料: プロパンー水菜一篦䒚, $P_{\mathrm{C} 3}{ }^{0}=0.063 \mathrm{~atm}$

*5 プロパンの場合初期反応速度 $r_{0}$ は反応率 $10 \%$ 以下の微 少反応率の領域で $r_{0}=(F / W) \cdot x$ より求めた。

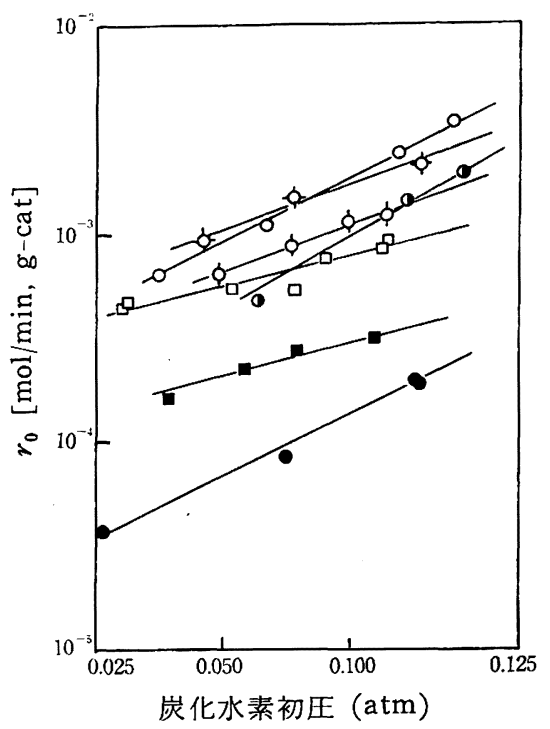

図 12 炭化水素分圧の影響

反応条件 $\mathrm{C}_{3} \mathrm{H}_{8}: P_{\mathrm{H} 2}{ }^{0}=0.74 \mathrm{~atm}, \mathrm{O}: 350^{\circ} \mathrm{C}, 300^{\circ} \mathrm{C}$ $P_{\mathrm{H}_{2}{ }^{0}}=0.84 \mathrm{~atm}, 0: 250^{\circ} \mathrm{C}$

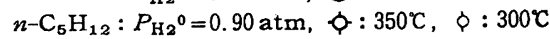
$n-\mathrm{C}_{6} \mathrm{H}_{14} ; P_{\mathrm{H}_{2}}{ }^{0}=0.88 \mathrm{~atm}, \square: 350^{\circ} \mathrm{C}$ $n-\mathrm{C}_{7} \mathrm{H}_{18} ; P_{\mathrm{H}_{2}}{ }^{\circ}=0.89 \mathrm{~atm}, \mathbf{\square}: 350^{\circ} \mathrm{C}$

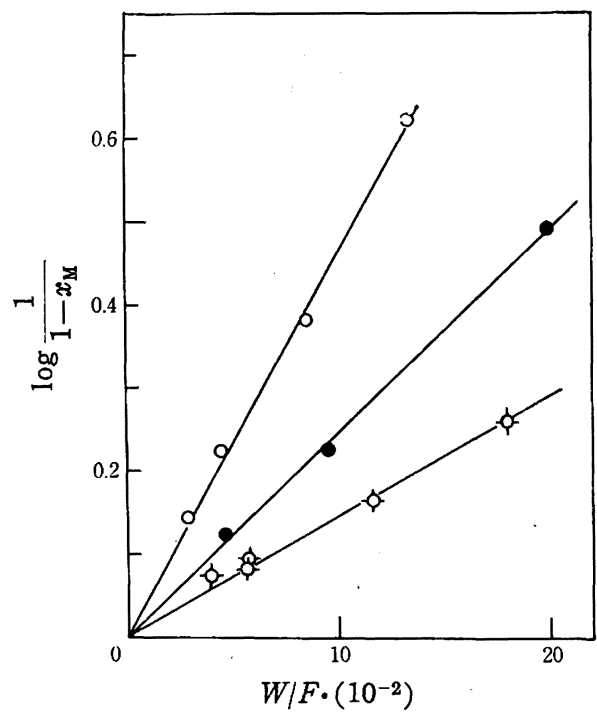

図 13 理論水素比の 1.5 倍以上の水素比に拈けるメタ ン化速度（擬 1 次）

反応条件 $\mathrm{O}: n-\mathrm{C}_{5} \mathrm{H}_{12}, 300^{\circ} \mathrm{C}, P_{\mathrm{C}_{5}}{ }^{0}=0.10 \mathrm{~atm}, P_{\mathrm{H}_{2}}{ }^{0}=0.90 \mathrm{~atm}$ - : $n-\mathrm{C}_{0} \mathrm{H}_{14}, 350 \mathrm{C}, P_{\mathrm{Ce}^{0}}=0.091 \mathrm{~atm}, P_{\mathrm{H}_{2}}{ }^{0}=0.90$ atm : : $n-\mathrm{C}_{7} \mathrm{H}_{18}, 350^{\circ} \mathrm{C}, P_{\mathrm{C}^{0}}{ }^{0}=0.083 \mathrm{~atm}, P_{\mathrm{H}_{2}}{ }^{0}=0.92 \mathrm{~atm}$

\section{4 考察}

以上の実験結果より初期反応速度について水素および炭化水素 の次数が $0 \sim 1$ 次となることから水素も炭化水素もニッケル上に 吸着していることが示唆される。また反応速度はある一定の水素 比以上で水素分王に対して 0 次となる。水素分圧でなく水素比に よってこの点が決まってくることから吸着点が水素と炭化水素で 異なるとは考えにくい。野崎ら゙) はニッケル上でのエタンの水素 化分解の研究で, $145^{\circ} \mathrm{C}$ では水素がエタンよりはるかに強く吸着 していることを報告している。水素の抑制作用が皮素が強く吸着 点を奪うためとすると，温度の上昇によりこの抑制作用がなくな

7）野崎文男，森川 清，尾崎 萃，触媒，4，8（1962）. 
ることは炭化水素の吸着がかなり強くなったことさ意味する。

ニッケル触媒上でのプロパンの水素化分解では反応は次の様式 で進行するといわれている8

$$
\mathrm{C}_{3} \mathrm{H}_{8} \rightleftarrows \mathrm{C}_{3} \mathrm{H}_{0}(\mathrm{a})+4 \mathrm{H}_{2}
$$

吸着し, これに水素が反応して, C-C 結合の切断が起こり, メタ ンが生成する。この C-C 結合の切断が律速段階とされている。

8) G. C. Bond, "Catalysis by Metal", Academic Press, London and New York (1962) p. 398.
表面吸着種 $\mathrm{C}_{3} \mathrm{H}_{0}$ の濃度が（ 5 ）式の平衡で水素分王によって抑 制されるので，水素による抑制作用があるといわれている。( 5 ) の反応は脱水素反応でめり，高温ほど平衡が右に傾いていると思 われる。したがって高温で水素による抑制作用がみられなくなる ことは炭化水素の吸着が水素に上って抑制されにくくなることに あるのであろら。

(昭和 42 年 3 ノ 31 月, 日本化学会第 20 年会講演)

\title{
コバルト塩および臭化物を触媒よする $n$-パラフィンの液相空気酸化
}

\author{
(昭 和 42 年 5 月 24 日 受 理)
}

\author{
峯英 司 ${ }^{* 1}$. 神谷 佳男 ${ }^{* 2}$
}

\begin{abstract}
nーパラフィンを脂肪酸溶液中でコバルト塩と臭化物を触媒として酸素酸化すると, $80^{\circ} \mathrm{C} に$ 扰いてす速やかに酸化が進行するこ とを見い出した。酸化速度はパラフィンの炭素数が 8 から 12 まではほとんど一定であるが，用いたアルカリ臭化物のアルカリ によって著しく変化し，速度の順序は $\mathrm{CoBr}_{2}>\mathrm{CaBr}_{2}>\mathrm{LiBr}>\mathrm{NaBr}>\mathrm{KBr}>\mathrm{NH}_{4} \mathrm{Br}$ であった。有効な強媒である臭化コバルトは

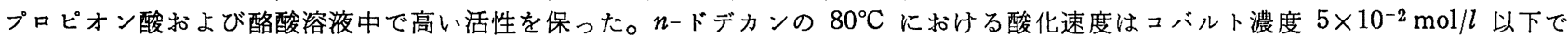
コバルトについて1次であるが, $10^{-1} \mathrm{~mol} / l$ 以上ではコバルト濃度が増加するほど減少した。酪酸中に打けるn-ドデカンの酸化

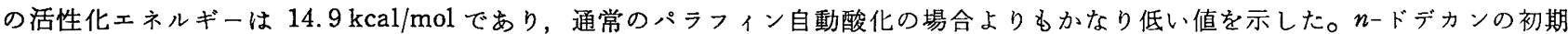
酸化生成物は主にドデカノンとドデカノールであるが，さらに酸化すると二酸化炭素や酢酸など分解生成物が増加した。
\end{abstract}

\section{1. 緒言}

最近, パラフィン類の有効利用法が注目されているが，液相空 気酸化によって種々の脂肪酸, アルコール,ケトン類などを合成 することが一つの有力な手段であろう。

工業的には，酢酸を製造する Distillers 法1)と Celanese 法2) が著名であり，パラフィンワックスの酸化による高級脂肪酸の製 造が大戦中ドイッに沶いて実施されたと言5。また，近年り連で はパラフィンの酸化について多数の研究4,5) が発表されて扣り， 高級アルコール,脂肪酸の製造が工業化されていると伝えられる。

理論的な研究としては Twigg(6), Benton ${ }^{7)}$, Arndt ${ }^{8)}$, Ema-

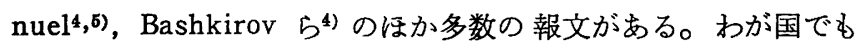
工藤 ${ }^{9)}$, 下村 ${ }^{10)}$ ，太田 $5^{11) ， 山 口 ら ~}{ }^{12)}$ の研究が発表されている。

*1 Eiji MINE 帝国人絹松山工場 : 松山市.

*2 Yoshio KAMIYA 東京大学工学部然料工学科：東京都文 京区本郷.

1）日特公, 昭 $30-4031,4215$.

2) Petrol. Refiner, 38, No. 11, 234 (1959) ; U. S. P., 2659746 (1953).

3) G. Wietzel, Chem. Eng. Sci. (Special Suppl), 3, 17 (1954).

4) N. M. Emanuel, "The Oxidation of Hydrocarbons in the Liquid Phase", Pergamon Press (1965)

5) N. M. Emanuel, E. T. Denisov, Russ. Chem. Rev., 29, 1409 (1960).

6) G. H. Twigg, Chem. Eng. Sci. (Special suppl), 3, 14 (1954).

7) J. L. Benton, Nature, 171, 269 (1953).

8) R. R. Arndt, J. B. Barbour, E. J. Engels, D. H. S. Horn, D. A. Sutton, J. Chem. Soc., 1959, 3258,
著者らの研究室に抽いて $p$-キシレンの酸化触媒として工業 的に著名な臭化コバルトの作用機構について検討を行なっており， テトラリン ${ }^{13)}$ ，エチルベンゼン ${ }^{14)}, p$-キシレン15)などについて実 験した結果，本触媒は Ravens が述べているような連鎖開始反応 に有効な触媒ではなくて，連鎖進行反応に有効なものであること を速度論的に確かめている。

連鎖進行過程に有効な触媒は, 通常の触媒が開始反応に有効で あるのと異なった特徵を有するので, 比較的酸化され難い $n$-パ ラフィンについて実験することは興味深い。主として $n$-ドデカ ンについて，コパルト濃度，臭化物の濃度および種類，有機酸溶 媒の種類、コバルト塩アニオンの種類などが反応速度におよぼす 効果ならびに酸化生成物について検討を行なった。

\section{2 実 験 方 法}

\section{$2 \cdot 1$ 酸化実験法}

酸素吸収速度は定圧式酸素吸収装置 ${ }^{17)} に よ り$ 測定した。反応容 器は約 $50 \mathrm{~m} l$ の長首丸底フラスコを用いた。

触某はデカン酸コバルト（調製法は後記）または酢酸コバルト （市販特級品）およびアルカリ臭化物を使用した。

9）工藤, 下村, 根岸, 福井, 工化, 65，52，1372，1379(1962)

10）下村, 日化, 84, 16 (1963).

11）太田, 砂岡, 山川, 加賀美, 有機合成化学, 18, 743 (1960).

12）山口ら, 石油学会誌, 12,822, 885 (1962) その他.

13) Y. Kamiya, Tetrahedron, 22, 2029 (1966).

14) 神谷, 工化, 69, 897 (1966).

15) Y.Kamiya, T. Nakajima, K. Sakota, Bull. Chem. Soc. Japan, 39, 2211 (1966).

16) D. A.S. Ravens, Trans. Faraday Soc., 55, 1768(1959).

17) 神谷, 工化, 68, 1877 (1965). 